\title{
Genetic Diversity Among Viruses Associated with Sugarcane Mosaic Disease in Tucumán, Argentina
}

\author{
M. F. Perera, M. P. Filippone, C. J. Ramallo, M. I. Cuenya, M. L. García, L. D. Ploper, and A. P. Castagnaro
}

First, second, and seventh authors: Sección Biotecnología de la Estación Experimental Agroindustrial Obispo Colombres (EEAOC)-Unidad Asociada al Instituto Superior de Investigaciones Biológicas (INSIBIO; CONICET-UNT), Av. William Cross 3150, C.P. T4101XAC, Las Talitas, Tucumán, Argentina; third and sixth authors: Sección Fitopatología, EEAOC, Las Talitas, Tucumán, Argentina; fourth author: Subprograma Mejoramiento Genético de la Caña de Azúcar, EEAOC, Las Talitas, Tucumán, Argentina; and fifth author: Instituto de Bioquímica y Biología Molecular, UNLP, CCT-La Plata, CONICET, Facultad de Ciencias Exactas, Universidad Nacional de La Plata, Calles 47 y 115. C.P. 1900, La Plata, Buenos Aires, Argentina.

Accepted for publication 18 September 2008.

\begin{abstract}
Perera, M. F., Filippone, M. P., Ramallo, C. J., Cuenya, M. I., García, M. L., Ploper, L. D., and Castagnaro, A. P. 2009. Genetic diversity among viruses associated with sugarcane mosaic disease in Tucumán, Argentina. Phytopathology 99:38-49.

Sugarcane leaves with mosaic symptoms were collected in 2006-07 in Tucumán (Argentina) and analyzed by reverse-transcriptase polymerase chain reaction (RT-PCR) restriction fragment length polymorphism (RFLP) and sequencing of a fragment of the Sugarcane mosaic virus (SCMV) and Sorghum mosaic virus (SrMV) coat protein (CP) genes. SCMV was detected in $96.6 \%$ of samples, with $41 \%$ showing the RFLP profile consistent with strain $\mathrm{E}$. The remaining samples produced eight

graphical origin, and sequence analyses of $\mathrm{CP}$ genes showed a greater genetic diversity compared with other studies. SrMV was detected in $63.2 \%$ of samples and most of these were also infected by SCMV, indicating that, unlike other countries and other Argentinean provinces, where high levels of co-infection are infrequent, co-existence is common in Tucumán. RFLP analysis showed the presence of SrMV strains M $(68 \%)$ and $\mathrm{I}(14 \%)$, while co-infection between $\mathrm{M}$ and $\mathrm{H}$ strains was present in $18 \%$ of samples. Other SCMV subgroup members and the Sugarcane streak mosaic virus (SCSMV) were not detected. Our results also showed that sequencing is currently the only reliable method to assess SCMV and SrMV genetic diversity, because RT-PCR-RFLP may not be sufficiently discriminating.
\end{abstract} different profiles that did not match other known strains. SCMV distribution seemed to be more related to sugarcane genotype than to geo-
Additional keywords: coat protein gene, Potyviridae.
Sugarcane mosaic, one of the most important viral diseases of sugarcane, is widely distributed in the world (24) and its economic significance varies among regions. Although not a major problem in some countries, sugarcane mosaic has caused substantial yield losses in other countries due to severe outbreaks. Economic losses depend on varietal susceptibility, virus strain, its interaction with other diseases, vector population, and environmental conditions (17). In the mid-1920s, a disease epidemic threatened the sugar industry in Argentina, Brazil, and Louisiana (United States) (24). The only effective way to control sugarcane mosaic has been the use of resistant cultivars (36). This requires a complete understanding of the genetic diversity of the pathogens as well as the interaction with cultivar, because resistance breakdown can occur when new strains or viruses appear (20). In addition, careful planning of crop management practices, including time of planting and harvesting, are used for disease control. Breeding for resistance has proven to be difficult due to the complexity of the sugarcane genome (22). As a consequence, susceptibility to Sugarcane mosaic virus (SCMV) still limits the cultivation of several elite sugarcane cultivars (25).

Numerous strains of SCMV and Sorghum mosaic virus (SrMV) are commonly associated with mosaic symptoms. Both viruses are members of the SCMV subgroup in the genus Potyvirus of the family Potyviridae. This family is the largest and economically most important group of plant viruses, with Potyvirus being its

Corresponding author: A. P. Castagnaro; E-mail address: atilio@eeaoc.org.ar

doi:10.1094/PHYTO-99-1-0038

(c) 2009 The American Phytopathological Society most significant genus (6). Four other viruses-Maize dwarf mosaic virus (MDMV), Johnsongrass mosaic virus (JGMV), Pennisetum mosaic virus (PenMV), and Zea mosaic virus (ZeMV)are also included in the SCMV subgroup although they have never been isolated from sugarcane (8). Another virus, Sugarcane streak mosaic virus (SCSMV), was recently identified (21) and is the major cause of mosaic symptoms in commercial sugarcane cultivars in several Asian countries (8). This virus could belong to an undescribed new genus within the Potyviridae family $(1,23)$ and can infect sugarcane simultaneously with SCMV (8).

Serological-based assays (24) and reverse-transcriptase polymerase chain reaction (RT-PCR) protocols (34) are currently available to identify SCMV and SrMV. Before 1997, however, the only reported method of distinguishing among different SCMV and SrMV strains was to inoculate differential hosts with sap extracted from infected plants and observe if the plants developed characteristic symptoms of the different virus strains. The strains differ in their host range, ability to cause infection, and severity. However, the use of host differentials is time consuming and labor intensive and, more importantly, it does not reveal the range of viral diversity. In 1997, Yang and Mirkov (38) were the first to report the development of an RT-PCR-based restriction fragment length polymorphism (RFLP) analysis protocol to distinguish between SCMV and SrMV as well as between strains within each virus. A pair of RT-PCR primers that amplified a fragment of the coat protein (CP) gene was used to detect SCMV and a second pair to detect SrMV. The N-terminal part of the CP is the most variable region and contains the major virus-specific antigenic determinants, whereas the core protein is highly conserved among various Potyvirus spp. $(31,33)$. The RT-PCR products were then 
subjected to an RFLP analysis to differentiate individual strains. The availability of the RT-PCR-based RFLP protocol provided a practical and efficient method to identify virus strains causing mosaic.

In Argentina, the sugarcane industry began in the province of Tucumán 190 years ago and, since then, different mosaic symptoms have been described in infected plants. The causal agent was first identified by Bennet (5) in 1941 as SCMV strain B. Two additional SCMV strains, A and F, and SrMV strain I, were detected in 1981 by biological assays (29). This strain identification, based on symptom expression and serological methods, has proven to be inconsistent and unreliable. In 2005, the predominance of SCMV strain E in Tucumán was determined by RTPCR-RFLP (13). More recently, using the same methodology, we obtained new RFLP profiles, indicating that potential new strains were present (27). Viral strain identification at the genomic level would provide valuable information for the development of appropriate in vitro diagnostic tests as well as for determining mechanisms for increased disease resistance (17).

The objective of this study was to continue the characterization of the viruses associated with sugarcane mosaic in northwestern Argentina, particularly in Tucumán, and to analyze their genetic diversity. The present study reveals that new SCMV and SrMV genotypes are prevalent in our region in association with mosaic disease and their genetic variability could be detected only through DNA sequence comparisons. Also, a high frequency of co-infection by both viruses was found only in Tucumán province.

\section{MATERIALS AND METHODS}

Samples. Seventy-six leaf samples from sugarcane showing severe (red leaf) and common mosaic symptoms were collected in the 2006-07 growing season from 37 sugarcane genotypes at seven locations in Tucumán, Argentina, where the local breeding program is conducted. Only one field was sampled at each location. Most leaf samples were taken from advanced breeding lines at the final testing stage before release to the sugar industry and the remainder sampled from commercial cultivars. All fields had been grown using standard agronomic practices. Genotypes that showed mosaic symptoms differed between locations; most genotypes were present at a single location, whereas only a few genotypes were present at several locations. In addition, 11 symptomatic samples from 10 sugarcane genotypes were collected in the provinces of Salta and Jujuy, Argentina, considered to be a different geographical and agroecological group (Table 1). Two leaves per sample were stored at $-70^{\circ} \mathrm{C}$ until extraction of the total plant RNA.

Extraction of total plant RNA. Frozen lamina tissue expressing mosaic symptoms $(\approx 200 \mathrm{mg})$ was placed in liquid nitrogen and ground in a mortar. Total RNA was extracted using the protocol described by Aljanabi et al. (4). The contaminant DNA was eliminated by DNAse treatment.

RT-PCR to detect SCMV and SrMV. RT-PCR was performed as described by Yang and Mirkov (38) and Alegria et al. (3). Firststrand cDNA was synthesized using the Maloney-Murine leukemia virus reverse transcriptase (M-MLV) (Promega Corp., Madison, WI) as recommended by the manufacturer, with the reverse primers as the initial primer. The virus-specific primers SCMVF3 (5'-TTTYCACCAAGCTGGAA-3'; Y = C or T) (38) or SCMVF4 (5'-GTTTTYCACCAAGCTGGAACAGTC-3'; Y = C or T) (3) /SCMVR3 (5'-AGCTGTGTGTCTCTCTGTATTCTC$\left.3^{\prime}\right)$ (38) and SrMVF3 (5'-AAGCAACAGCACAAGCAC-3') /SrMVR3 (5'-TGACTCTCACCGACATTCC-3') (38) were used to detect SCMV and SrMV, respectively, in the PCR assay. The PCR reaction mix (40- $\mu$ l final volume) consisted of $7.5 \mu \mathrm{l}$ of cDNA, $250 \mathrm{ng}$ of each primer, $1 \times$ PCR buffer (Promega Corp.), $1.5 \mathrm{mM} \mathrm{MgCl} 2$ (Promega Corp.), $100 \mu \mathrm{M}$ dNTPs (Amersham Biosciences, Piscataway, NJ), 0.6 units of Taq DNA polymerase
(Promega Corp.), and diethylpyrocarbonate (DEPC) water (USB Corp., Cleveland, $\mathrm{OH}$ ) to final volume. PCR cycling parameters for SCMV using SCMVF4 and SCMVR3 primers were 1 cycle at $94^{\circ} \mathrm{C}(15 \mathrm{~min}) ; 35$ cycles at $94^{\circ} \mathrm{C}(1 \mathrm{~min}), 60^{\circ} \mathrm{C}(1 \mathrm{~min})$, and $72^{\circ} \mathrm{C}(1 \mathrm{~min})$; and a final cycle at $72^{\circ} \mathrm{C}$ for $5 \mathrm{~min}$. For SCMV using SCMVF3 and SCMVR3 primers and for SrMV, the cycle parameters were 1 cycle at $94^{\circ} \mathrm{C}(15 \mathrm{~min}) ; 35$ cycles at $94^{\circ} \mathrm{C}$ $(1 \mathrm{~min}), 52^{\circ} \mathrm{C}(1 \mathrm{~min})$, and $72^{\circ} \mathrm{C}(2 \mathrm{~min})$; and a final cycle at $72^{\circ} \mathrm{C}$ for $7 \mathrm{~min}$. Upon completion, $5 \mu \mathrm{l}$ of the RT-PCR sample was mixed with $1 \mu \mathrm{l}$ of $6 \times$ gel loading buffer and electrophoresed in a $1.5 \%$ agarose gel. After electrophoresis, the gel was stained with ethidium bromide and visualized with UV light. The size of the fragment amplified from leaves infected with SCMV was $\approx 900 \mathrm{bp}$ and that from leaves infected with SrMV was $\approx 870 \mathrm{bp}$.

RFLPs. Once the virus identities were determined using RTPCR, RFLP was performed to determine the virus strain according to the protocol of Yang and Mirkov (38). The CP genes amplified by RT-PCR contain different restriction sites that can be used to differentiate strains (38). The PCR-amplified products were precipitated from the reaction mix by the addition of $1 / 10$ volume of $3 \mathrm{M}$ sodium acetate, $\mathrm{pH} 5.2$, and 2.5 volumes of $100 \%$ ethanol. The pellets were washed twice with $70 \%$ ethanol and dissolved in $10 \mu \mathrm{l}$ of distilled water. The PCR products generated from SCMV were digested with restriction enzymes TaqI (T/CGA) (Promega Corp.) at $65^{\circ} \mathrm{C}$ for $2 \mathrm{~h}$ and HinfI (G/ANTC) (Promega Corp.) at $37^{\circ} \mathrm{C}$ for $2 \mathrm{~h}$ and those from SrMV were digested with $\mathrm{HgaI}$ (GACGCNNNNN/) (Promega Corp.) at $37^{\circ} \mathrm{C}$ for $2 \mathrm{~h}$. The digestion reactions were carried out in a final volume of $15 \mu \mathrm{l}$, using 0.3 units/ $\mu$ l of enzyme. The digestion products were analyzed on a $1.8 \%$ agarose gel stained with ethidium bromide.

Cloning and sequencing of the RT-PCR product from SCMV and SrMV isolates. The RT-PCR products belonging to the different RFLP profiles of SCMV and SrMV were gel purified using the QIAquick Gel Extraction Kit (Qiagen Inc., Chatsworth, $\mathrm{CA}$ ), cloned into the pGEM-T Easy vector (Promega Corp.) following the manufacturer's protocol, and transformed into Escherichia coli DH5 $\alpha$ cells. Recombinant pGEM-T Easy clones were chosen based on EcoRI (G/AATTC) (Promega Corp.) restriction analysis. Forty-seven clones were sequenced on an automated DNA Sequencer (Abi 3130xl Genetic Analyzer, Hitachi) using SP6 (5'-CATACGATTTAGGTGACACTATAG-3') and T7 (5'-TAATACGACTCACTATAGGG-3') primers. Nucleotide sequences obtained in both directions were used to create the complete sequence of SCMV and SrMV CP genes. The restriction analysis and the determination of nucleotide identity were conducted using the DNAMan software (Lynnon BioSoft, Vaudreuil, Quebec, Canada). The regions (amplicon without primer sequences) of 852 and 834 bp for SCMV and SrMV, respectively, from the CP encoding region were aligned and their phylogeny determined by ClustalX (35) using the neighbor-joining option with a bootstrap analysis of 1,000 random replications. Sequences from GenBank were also included in the analysis

RT-PCR and restriction analysis to differentiate members of the SCMV subgroup. RT-PCR was performed according to the protocol described by Marie-Jeanne et al. (26) with modifications. First-strand cDNA was synthesized using the M-MLV (Promega Corp.) following the manufacturer's protocol, with the reverse primer as the initial primer. The virus-specific primers Oligoln (5'-ATGGTHTGGTGYATHGARAAYGG-3'; $\mathrm{H}=\mathrm{A}, \mathrm{C}$ or $\mathrm{T}$; $\mathrm{Y}=\mathrm{C}$ or $\mathrm{T} ; \mathrm{R}=\mathrm{A}$ or $\mathrm{G})$ and Oligo2n (5'-TGCTGCKGCYTTCATYTG-3'; Y = C or T; $\mathrm{K}=\mathrm{G}$ or $\mathrm{T}$ ) were used to detect members of the SCMV subgroup in the PCR assay. The PCR reaction mix (40- $\mu$ l final volume) consisted of $7.5 \mu \mathrm{l}$ of cDNA, $300 \mathrm{ng}$ of each primer, 1× PCR buffer (Promega Corp.), $1.25 \mathrm{mM} \mathrm{MgCl}{ }_{2}$ (Promega Corp.), $50 \mu \mathrm{M}$ dNTPs (Amersham Biosciences), 0.6 units of Taq DNA polymerase (Promega Corp.), and DEPC water (USB Corp.) to final volume. PCR cycling parameters were 1 cycle at $94^{\circ} \mathrm{C}(5 \mathrm{~min}), 50^{\circ} \mathrm{C}(2 \mathrm{~min})$, and $72^{\circ} \mathrm{C}$ 
(50 s); 1 cycle at $94^{\circ} \mathrm{C}(2 \mathrm{~min}), 50^{\circ} \mathrm{C}(2 \mathrm{~min})$, and $72^{\circ} \mathrm{C}(50 \mathrm{~s}) ; 30$ cycles at $94^{\circ} \mathrm{C}(45 \mathrm{~s}), 50^{\circ} \mathrm{C}(2 \mathrm{~min})$, and $72^{\circ} \mathrm{C}(50 \mathrm{~s})$; and a final cycle at $72^{\circ} \mathrm{C}$ for $10 \mathrm{~min}$. The reaction mixture $(5 \mu \mathrm{l})$ was analyzed on $1.5 \%$ agarose gel stained with ethidium bromide. The size of the fragment amplified from leaves infected with members of the SCMV subgroup was $327 \mathrm{bp}$. The PCR-amplified products were precipitated from the reaction mix by the addition of $1 / 10$ volume of $3 \mathrm{M}$ sodium acetate, $\mathrm{pH} 5.2$, and 2.5 volumes of $100 \%$ ethanol. The pellets were washed twice with $70 \%$ ethanol and dissolved in $10 \mu \mathrm{l}$ of distilled water. They were then digested with restriction enzymes AluI (AG/CT) (Promega Corp.) and DdeI (C/TNAG) (Promega Corp.) at $37^{\circ} \mathrm{C}$ for $2 \mathrm{~h}$. The digestion reactions were carried out in a final volume of $15 \mu \mathrm{l}$ using 0.3 units $/ \mu \mathrm{l}$ of enzyme. The digestion products were analyzed on a $1.8 \%$ agarose gel stained with ethidium bromide.

RT-PCR to detect SCSMV. RT-PCR was performed according to the protocol of Chatenet et al. (8) with modifications. Firststrand cDNA was synthesized using the M-MLV (Promega Corp.) according to the manufacturer's instructions, with the reverse primer as the initial primer. The virus-specific primers ST2 and ST5 (unpublished sequences; generously supplied by P. Rott, CIRAD, Montpellier, France) were used to detect SCSMV in the PCR assay. The PCR reaction mix (20- $\mu$ l final volume) consisted of $7.5 \mu \mathrm{l}$ of cDNA, $250 \mathrm{ng}$ of each primer, $1 \times$ PCR buffer (Promega Corp.), $1.5 \mathrm{mM} \mathrm{MgCl}_{2}$ (Promega Corp.), $200 \mu \mathrm{M}$ dNTPs (Amersham Biosciences), 0.6 units of Taq DNA polymerase

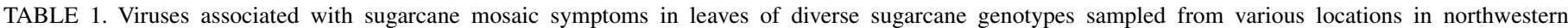
Argentina

\begin{tabular}{|c|c|c|c|c|c|c|}
\hline \multirow[b]{2}{*}{ Location, genotype ${ }^{a}$} & \multirow[b]{2}{*}{ Symptoms ${ }^{\mathrm{b}}$} & \multirow[b]{2}{*}{ Date of field sampling } & \multicolumn{4}{|c|}{ Virus detection by RT-PCR ${ }^{c}$} \\
\hline & & & $\mathrm{SCMV}^{\mathrm{d}}$ & SrMVe $^{\mathrm{e}}$ & SCSMV $^{f}$ & Subgroup $^{g}$ \\
\hline \multicolumn{7}{|l|}{ Tucumán(*) } \\
\hline \multicolumn{7}{|l|}{ Mercedes } \\
\hline CP 65-357 & Common & 4 January 2006 & + & + & - & + \\
\hline CP 65-357 & Common & 4 January 2006 & + & + & - & + \\
\hline TUC 93-89 & Severe & 4 January 2006 & + & + & - & + \\
\hline TUC 94-12 & Common & 4 January 2006 & - & + & - & + \\
\hline TUC 95-17 & Severe & 4 January 2006 & + & + & - & + \\
\hline TUC 95-17 & Severe & 4 January 2006 & + & + & - & + \\
\hline TUC 95-18 & Severe & 4 January 2006 & + & + & - & + \\
\hline TUC 96-43 & Severe & 4 January 2006 & + & + & - & + \\
\hline TUC 96-43 & Severe & 4 January 2006 & + & - & - & + \\
\hline TUC 97-4 & Severe & 4 January 2006 & + & + & - & + \\
\hline TUC 97-19 & Common & 4 January 2006 & + & + & - & + \\
\hline \multicolumn{7}{|l|}{ Palá-Palá } \\
\hline CP 65-357 & Common & 4 January 2006 & + & + & - & + \\
\hline TUC 93-104 & Common & 4 January 2006 & - & + & - & + \\
\hline TUC 95-17 & Common & 4 January 2006 & + & + & - & + \\
\hline TUC 97-21 & Common & 4 January 2006 & + & + & - & + \\
\hline \multicolumn{7}{|l|}{ Fronterita } \\
\hline CP 65-357 & Common & 4 January 2006 & + & + & - & + \\
\hline TUC 95-17 & Severe & 4 January 2006 & + & + & - & + \\
\hline \multicolumn{7}{|l|}{ Los Córdoba } \\
\hline CP 65-357 & Common & 5 January 2006 & + & + & - & + \\
\hline CP 65-357 & Common & 5 January 2006 & + & + & - & + \\
\hline TUC 93-58 & Common & 5 January 2006 & + & + & - & + \\
\hline TUC 93-58 & Severe & 5 January 2006 & + & - & - & + \\
\hline TUC 93-89 & Common & 5 January 2006 & + & + & - & + \\
\hline TUC 93-104 & Common & 5 January 2006 & + & + & - & + \\
\hline TUC 95-17 & Common & 5 January 2006 & + & + & - & + \\
\hline TUC 95-17 & Common & 5 January 2006 & + & - & - & + \\
\hline TUC 95-18 & Severe & 5 January 2006 & + & + & - & + \\
\hline TUC 95-59 & Common & 5 January 2006 & + & + & - & + \\
\hline TUC 96-24 & Common & 5 January 2006 & + & + & - & + \\
\hline TUC 97-4 & Common & 5 January 2006 & + & + & - & + \\
\hline \multicolumn{7}{|l|}{ Yaquilo } \\
\hline CP 65-357 & Common & 5 January 2006 & + & + & - & + \\
\hline TUC 93-89 & Common & 5 January 2006 & + & + & - & + \\
\hline TUC 95-17 & Common & 5 January 2006 & + & + & - & + \\
\hline TUC 96-24 & Common & 5 January 2006 & + & + & - & + \\
\hline TUC 97-8 & Common & 5 January 2006 & + & + & - & + \\
\hline TUC 97-8 & Severe & 5 January 2006 & + & - & - & + \\
\hline \multicolumn{7}{|l|}{ Santa Ana } \\
\hline CP 65-357 & Common & 19 January 2006 & + & + & - & + \\
\hline
\end{tabular}

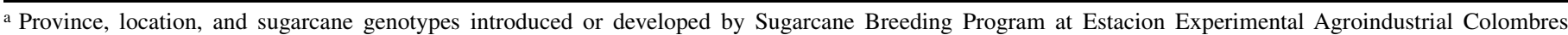
$($ EEAOC, *) and at Chacra Experimental Colonia Santa Rosa (**). Local genotype identities are assigned by each program. The genotypes from Salta and Jujuy provinces were considered as a different geographical and agroecological group.

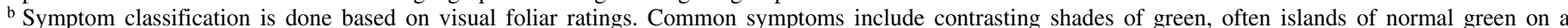
background of paler green or yellowish areas. Severe symptoms include extensive yellowing and, eventually, reddish flecks, streaks and spots along the leaves.

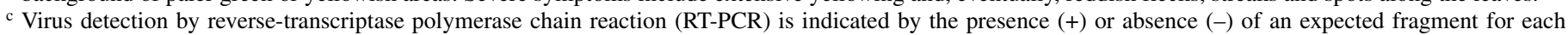
virus.

${ }^{\mathrm{d}}$ Sugarcane mosaic virus (SCMV). Expected fragment: 900 bp (3).

e Sorghum mosaic virus (SrMV). Expected fragment: 870 bp (38).

f Sugarcane streak mosaic virus (SCSMV). Expected fragment: 400 bp (8).

g SCMV subgroup. Expected fragment: 327 bp (26). 
(Promega Corp.), and DEPC water (USB Corp.) to final volume. PCR cycling parameters were 1 cycle at $94^{\circ} \mathrm{C}(15 \mathrm{~min}) ; 30$ cycles at $94^{\circ} \mathrm{C}(1 \mathrm{~min}), 50^{\circ} \mathrm{C}(1 \mathrm{~min})$, and $72^{\circ} \mathrm{C}(1 \mathrm{~min})$; and a final cycle at $72^{\circ} \mathrm{C}$ for $5 \mathrm{~min}$. The reaction mixture $(10 \mu \mathrm{l})$ was analyzed on a $1.5 \%$ agarose gel stained with ethidium bromide. The size of the fragment amplified from leaves infected with SCSMV was $400 \mathrm{bp}$.

\section{RESULTS}

Detection of SCMV and SrMV. SCMV- and SrMV-specific cDNA fragments were amplified by the RT-PCR assay from total RNA from leaves of the plants showing mosaic symptoms. A fragment of $\approx 900$ bp was amplified by primers SCMV F3/R4 from 84 samples (final percentage of infected samples, 96.6\%). A fragment of $\approx 870$ bp was amplified by primers SrMV F3/R3 from 55 samples (final percentage of infected samples, 63.2\%). Fiftytwo samples $(59.8 \%)$ were found to be infected by both SCMV and SrMV, whereas 32 samples $(36.8 \%)$ were infected only by SCMV and 3 samples (3.4\%) only by SrMV. Co-infection between SCMV and SrMV was found only in samples from Tucumán. Samples from Salta and Jujuy provinces, considered to be a different geographical and agroecological group, were infected only by SCMV (Table 1). There was no correlation between the severity of the symptoms and the viruses identified; however, the virus concentration was higher among genotypes

TABLE 1. (continued from preceding page)

\begin{tabular}{|c|c|c|c|c|c|c|}
\hline \multirow[b]{2}{*}{ Location, genotype ${ }^{a}$} & \multirow[b]{2}{*}{ Symptoms ${ }^{\mathrm{b}}$} & \multirow[b]{2}{*}{ Date of field sampling } & \multicolumn{4}{|c|}{ Virus detection by RT-PCR ${ }^{c}$} \\
\hline & & & $\mathrm{SCMV}^{\mathrm{d}}$ & $\mathrm{SrMV}^{\mathrm{e}}$ & SCSMV $^{f}$ & Subgroup \\
\hline CP 65-357 & Common & 19 January 2006 & + & + & - & + \\
\hline TUC 94-58 & Common & 19 January 2006 & + & + & - & + \\
\hline TUC 95-59 & Severe & 19 January 2006 & + & + & - & + \\
\hline TUC 95-60 & Common & 19 January 2006 & + & + & - & + \\
\hline TUC 95-61 & Common & 19 January 2006 & + & + & - & + \\
\hline TUC 96-27 & Common & 19 January 2006 & + & + & - & + \\
\hline TUC 96-46 & Common & 19 January 2006 & + & + & - & + \\
\hline TUC 96-54 & Severe & 19 January 2006 & + & + & - & + \\
\hline TUC 96-55 & Common & 19 January 2006 & + & + & - & + \\
\hline TUC 96-56 & Severe & 19 January 2006 & + & + & - & + \\
\hline TUC 97-4 & Severe & 19 January 2006 & + & - & - & + \\
\hline TUC 97-5 & Severe & 19 January 2006 & + & + & - & + \\
\hline TUC 97-10 & Common & 19 January 2006 & + & + & - & + \\
\hline TUC 97-11 & Severe & 19 January 2006 & + & + & - & + \\
\hline TUC 97-15 & Severe & 19 January 2006 & + & + & - & + \\
\hline TUC 98-23 & Severe & 19 January 2006 & + & + & - & + \\
\hline TUC 98-39 & Common & 19 January 2006 & + & + & - & + \\
\hline TUC 98-53 & Severe & 19 January 2006 & + & + & - & + \\
\hline TUC 98-55 & Common & 19 January 2006 & + & + & - & + \\
\hline TUC 99-5 & Common & 19 January 2006 & + & + & - & + \\
\hline TUC 99-7 & Common & 19 January 2006 & - & + & - & + \\
\hline TUC 99-15 & Severe & 19 January 2006 & + & + & - & + \\
\hline TUC 00-29 & Severe & 19 January 2006 & + & + & - & + \\
\hline TUC 00-9 & Common & 19 January 2006 & + & + & - & + \\
\hline \multicolumn{7}{|l|}{ Las Talitas } \\
\hline RA 87-3 & Common & 25 June 2007 & + & - & - & + \\
\hline RA 87-3 & Common & 25 June 2007 & + & - & - & + \\
\hline RA 87-3 & Common & 25 June 2007 & + & - & - & + \\
\hline RA 87-3 & Common & 25 June 2007 & + & - & - & + \\
\hline RA 87-3 & Common & 25 June 2007 & + & - & - & + \\
\hline RA 87-3 & Common & 25 June 2007 & + & - & - & + \\
\hline RA 87-3 & Common & 25 June 2007 & + & - & - & + \\
\hline RA 87-3 & Common & 25 June 2007 & + & - & - & + \\
\hline RA 87-3 & Common & 25 June 2007 & + & - & - & + \\
\hline RA 87-3 & Common & 25 June 2007 & + & - & - & + \\
\hline RA 87-3 & Common & 25 June 2007 & + & - & - & + \\
\hline RA 87-3 & Common & 25 June 2007 & + & - & - & + \\
\hline RA 87-3 & Common & 25 June 2007 & + & - & - & + \\
\hline RA 87-3 & Common & 25 June 2007 & + & - & - & + \\
\hline RA 87-3 & Common & 25 June 2007 & + & - & - & + \\
\hline RA 87-3 & Common & 25 June 2007 & + & - & - & + \\
\hline \multicolumn{7}{|l|}{ Salta(**) } \\
\hline \multicolumn{7}{|l|}{ Tabacal } \\
\hline NA 84-3419 & Common & 24 July 2007 & + & - & - & + \\
\hline NA 89-3013 & Common & 24 July 2007 & + & - & - & + \\
\hline \multicolumn{7}{|l|}{ Colonia Santa Rosa } \\
\hline $\mathrm{CO} 419$ & Common & 25 July 2007 & + & - & - & + \\
\hline CP 52-68 & Common & 25 July 2007 & + & - & - & + \\
\hline CP $85-1625$ & Common & 25 July 2007 & + & - & - & + \\
\hline NA 84-347 & Common & 25 July 2007 & + & - & - & + \\
\hline NA $87-661$ & Common & 25 July 2007 & + & - & - & + \\
\hline NA 89-104 & Common & 25 July 2007 & + & - & - & + \\
\hline NA $90-244$ & Common & 25 July 2007 & + & - & - & + \\
\hline \multicolumn{7}{|l|}{ Jujuy(**) } \\
\hline \multicolumn{7}{|l|}{ Ledesma } \\
\hline CP 70-1133 & Common & 24 July 2007 & + & - & - & + \\
\hline NA 84-3419 & Common & 24 July 2007 & + & - & - & + \\
\hline
\end{tabular}


expressing the red-leaf symptoms (severe mosaic) compared with those showing mosaic symptoms only (common mosaic) (data not shown). The modification introduced to the protocol of Yang and Mirkov (38) by Alegria et al. (3) enhanced the detection of SCMV in our samples, because more positive samples were detected with this new protocol $(96.6 \%)$ than with the former one $(81.6 \%)$.

RFLP analysis. The differentiation of virus strain was performed as previously described (38). We found nine different RFLP profiles produced by the TaqI and HinfI digestions for

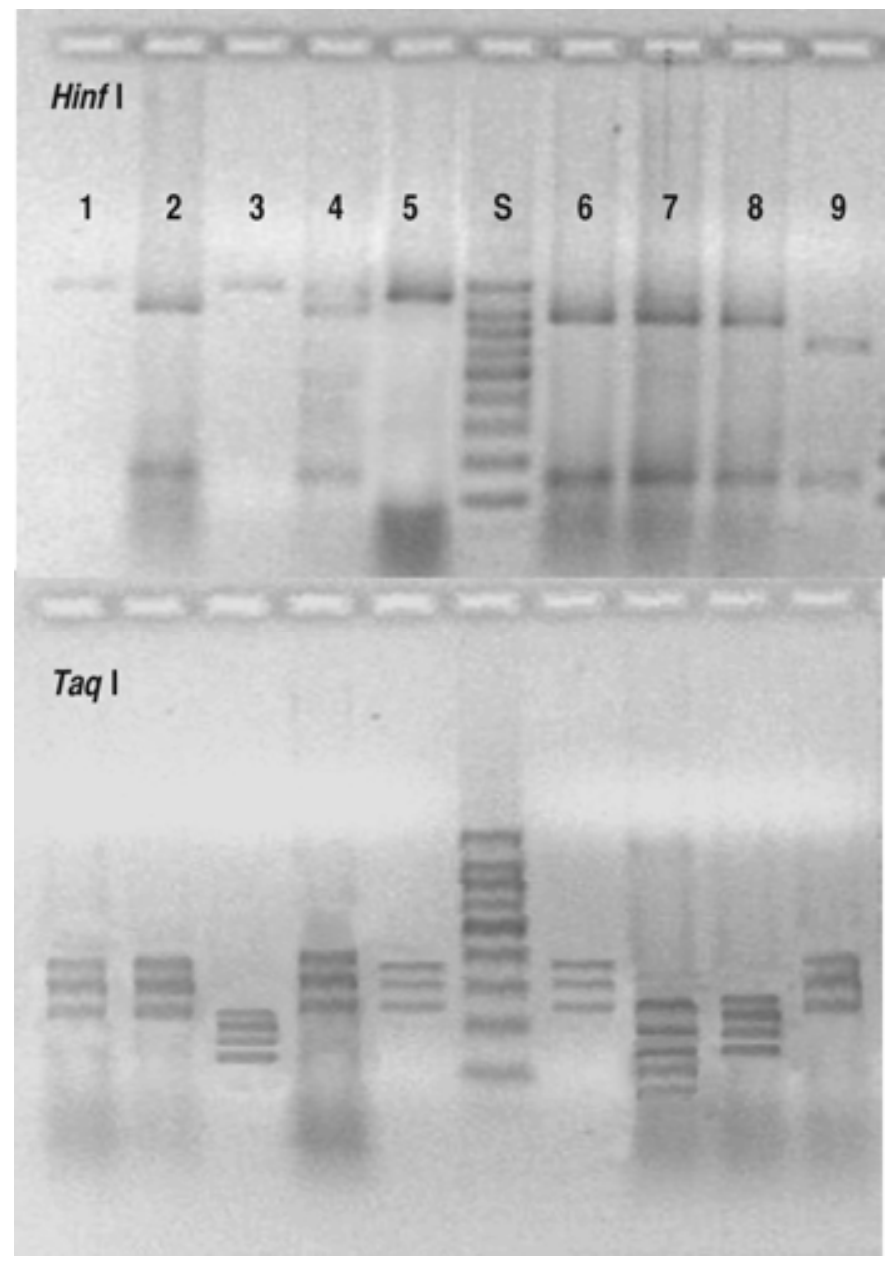

Fig. 1. Restriction fragment length polymorphisms (RFLPs) of reversetranscriptase polymerase chain reaction products from Sugarcane mosaic virus strains with HinfI (top) and $T a q I$ (bottom) digests. Lanes 1 to 9: the nine different RFLP profiles obtained. $\mathrm{S}=$ molecular weight markers (100 MarkerPromega; top to bottom: $1.000,900,800,700,600,500,400,300,200$, and $100 \mathrm{bp})$.
SCMV. The nine profiles (Fig. 1), the percentage of occurrence, and the size in nucleotides of the fragments generated (Table 2) are shown. RFLP profiles of $41 \%$ of the SCMV-positive samples coincided with strain E (profile 2), whereas the other eight profiles showed complex patterns of polymorphisms that did not totally match with other known strains of SCMV. The RFLP analyses of the SrMV-specific PCR products with HgaI indicated the existence of three known SrMV strains: H, I, and M (Fig. 2). We found strains $\mathrm{M}$ and $\mathrm{I}$ in 68 and $14 \%$ of the samples, respectively, whereas strain $\mathrm{H}$ was found in association with strain $\mathrm{M}$ in only $18 \%$ of the samples. Nevertheless, no association between the kind of RFLP profiles of SCMV and SrMV was detected, indicating that there was no relationship between the SCMV and SrMV strains found in co-infected samples.

Analysis of the CP gene sequences. To investigate the viral genetic diversity, the RT-PCR fragments belonging to each RFLP profile were purified, cloned into a vector, and sequenced. The SCMV isolates were named with a number equivalent to the nine RFLP profiles and a letter corresponding to the different isolates belonging to each profile. The SrMV isolates were designated with a letter corresponding to the three RFLP profiles $(\mathrm{M}, \mathrm{H}$, and I) (Fig. 2) and a number corresponding to the different isolates belonging to each profile. The GenBank accession numbers of each sequence are shown in Table 3. The CP-encoding region was aligned and differences were found through the entire sequence of

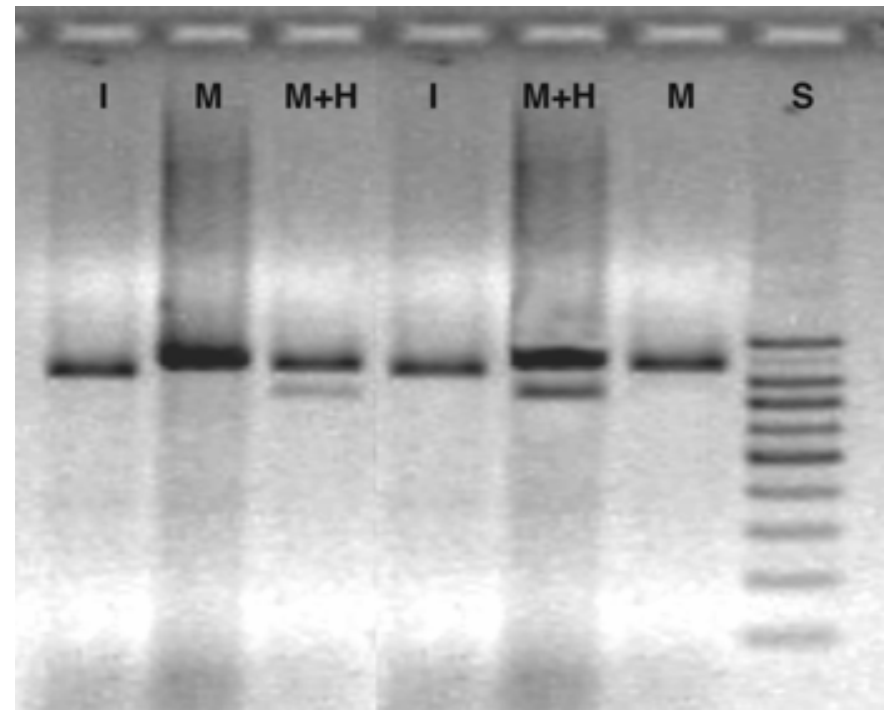

Fig. 2. Restriction fragment length polymorphisms (RFLPs) of reversetranscriptase polymerase chain reaction products from Sorghum mosaic virus strains with $\mathrm{HgaI}$ digests. I, M, and $\mathrm{H}=\mathrm{SrMV}$ strains; $\mathrm{S}=$ molecular weight markers (100 Marker-Promega; top to bottom: 1.000, 900, 800, 700, 600, 500, 400, 300, 200, and $100 \mathrm{bp})$.

TABLE 2. Incidence of each Sugarcane mosaic virus profile and size of restriction fragments obtained after digestion by HinfI and TaqI of the product amplified by reverse-transcriptase polymerase chain reaction

\begin{tabular}{|c|c|c|c|c|c|c|c|c|c|c|c|c|c|c|c|c|c|c|}
\hline \multirow[b]{3}{*}{ RFLPa $^{\mathrm{a}}$} & \multirow[b]{3}{*}{ Incidence $(\%)$} & \multicolumn{17}{|c|}{ Fragment size (bp) } \\
\hline & & \multicolumn{7}{|c|}{ HinfI } & \multicolumn{10}{|c|}{ TaqI } \\
\hline & & 128 & 142 & 330 & 428 & 630 & 758 & 900 & 24 & 81 & 153 & 159 & 208 & 240 & 275 & 312 & 324 & 361 \\
\hline 1 & 43.80 & $\ldots$ & $\ldots$ & $\ldots$ & $\ldots$ & $\ldots$ & $\ldots$ & $\mathrm{x}$ & $\mathrm{X}$ & $\ldots$ & $\ldots$ & $\ldots$ & $\ldots$ & $\mathrm{x}$ & $\mathrm{x}$ & $\ldots$ & $\ldots$ & $\mathrm{x}$ \\
\hline 2 & 41.00 & $\ldots$ & $\mathrm{x}$ & $\ldots$ & $\ldots$ & $\ldots$ & $\mathrm{x}$ & $\ldots$ & $\mathrm{x}$ & $\ldots$ & $\ldots$ & $\ldots$ & $\ldots$ & $\mathrm{x}$ & $\mathrm{x}$ & $\ldots$ & $\ldots$ & $\mathrm{x}$ \\
\hline 3 & 5.50 & $\ldots$ & $\ldots$ & $\ldots$ & $\ldots$ & $\ldots$ & $\ldots$ & $\mathrm{x}$ & $\mathrm{x}$ & $\ldots$ & $\mathrm{x}$ & $\ldots$ & $\mathrm{x}$ & $\mathrm{x}$ & $\mathrm{x}$ & $\ldots$ & $\ldots$ & $\ldots$ \\
\hline 4 & 2.70 & $\ldots$ & $\mathrm{x}$ & $\mathrm{x}$ & $\mathrm{x}$ & $\ldots$ & $\ldots$ & $\ldots$ & $\mathrm{x}$ & $\ldots$ & $\ldots$ & $\ldots$ & $\ldots$ & $\mathrm{x}$ & $\mathrm{X}$ & $\ldots$ & $\ldots$ & $\mathrm{x}$ \\
\hline 5 & 1.40 & $\ldots$ & $\ldots$ & $\ldots$ & $\ldots$ & $\ldots$ & $\ldots$ & $\mathrm{x}$ & $\mathrm{x}$ & $\ldots$ & $\ldots$ & $\ldots$ & $\ldots$ & $\mathrm{x}$ & $\ldots$ & $\mathrm{x}$ & $\mathrm{x}$ & $\ldots$ \\
\hline 6 & 1.40 & $\ldots$ & $\mathrm{x}$ & $\ldots$ & $\ldots$ & $\ldots$ & $\mathrm{x}$ & $\ldots$ & $\mathrm{x}$ & $\ldots$ & $\ldots$ & $\ldots$ & $\ldots$ & $\mathrm{x}$ & $\ldots$ & $\mathrm{x}$ & $\mathrm{x}$ & $\ldots$ \\
\hline 7 & 1.40 & $\ldots$ & $\mathrm{x}$ & $\ldots$ & $\ldots$ & $\ldots$ & $\mathrm{X}$ & $\ldots$ & $\mathrm{x}$ & $\mathrm{x}$ & $\mathrm{x}$ & $\mathrm{x}$ & $\mathrm{x}$ & $\ldots$ & $\mathrm{x}$ & $\ldots$ & $\ldots$ & $\ldots$ \\
\hline 8 & 1.40 & $\ldots$ & $\mathrm{x}$ & $\ldots$ & $\ldots$ & $\ldots$ & $\mathrm{x}$ & $\ldots$ & $\mathrm{x}$ & $\ldots$ & $\mathrm{X}$ & $\ldots$ & $\mathrm{x}$ & $\mathrm{x}$ & $\mathrm{x}$ & $\ldots$ & $\ldots$ & $\ldots$ \\
\hline 9 & 1.40 & $\mathrm{x}$ & $\mathrm{x}$ & $\ldots$ & $\ldots$ & $\mathrm{x}$ & $\ldots$ & $\ldots$ & $\mathrm{x}$ & $\ldots$ & $\ldots$ & $\ldots$ & $\ldots$ & $\mathrm{X}$ & $\mathrm{x}$ & $\ldots$ & $\ldots$ & $\mathrm{x}$ \\
\hline
\end{tabular}

a Restriction fragment length polymorphism profile. 
SCMV and SrMV. No gaps were detected within each group of sequences (Figs. 3 and 4).

The cloned fragments of SCMV contained 900 nucleotides (nt) and encoded 300 amino acids (aa); for SrMV, they contained $871 \mathrm{nt}$ and encoded 290 aa. The nucleotide sequence identity ranged from 95.89 to $99.88 \%$ within the SCMV group (data not shown). When pairwise comparisons of the nucleotide sequences were performed, all the SCMV sequences, even those classified as SCMV strain E (profile 2), had a higher nucleotide identity with SCMV strain E (95.66 to $97.07 \%$ ) than with the other strains (A, $\mathrm{B}$, and D) reported by Yang and Mirkov (38). However, our sequences shared the highest identity with Australian strains AF006735 and AF278405 (96.60 to $97.89 \%$ and 99.00 to $99.90 \%$, respectively) (Table 4). Within the SrMV group, the nucleotide sequence identity ranged from 97.36 to $99.88 \%$ (data not shown).
When pairwise comparisons were performed, the sequences of the SrMV strains predicted as H, M, and I by RFLP analysis did not yield the highest expected nucleotide identity with the sequences of the corresponding strains reported by Yang and Mirkov (38) (Table 5).

Phylogenetic analysis. The phylogenetic tree was constructed based on the nucleotide sequence alignment of the core region of the CP gene from the $35 \mathrm{SCMV}$ and 12 SrMV different sequences obtained. Nine sequences of the $\mathrm{CP}$ gene from known viruses (obtained from GenBank) were included for comparisons (Fig. 5). As expected, the SCMV and SrMV isolates were clustered in independent branches. No correlation was observed between the SCMV groups and the geographical origin of the SCMV isolates. Nevertheless, the isolates from Salta (1.N, 1.O, 2.E, 8.A, 8.B, and 9.A) and Jujuy (4.A and 4.B) belonged to different branches. A

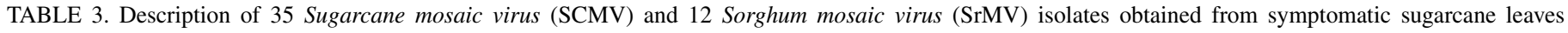
sampled from various locations in northwestern Argentina

\begin{tabular}{|c|c|c|c|c|}
\hline Virus, isolate $^{\mathrm{a}}$ & Province (location) & Sugarcane genotype ${ }^{b}$ & Genotype abbreviation $^{c}$ & GenBank accession no. \\
\hline \multicolumn{5}{|l|}{ SCMV } \\
\hline 1.A & Tucumán (Fronterita) & CP 65-357 & CP357 & EU196421 \\
\hline 1.B & Tucumán (Fronterita) & CP 65-357 & CP357 & EU196422 \\
\hline 1.C & Tucumán (Fronterita) & CP 65-357 & CP357 & EU196423 \\
\hline 1.D & Tucumán (Los Córdoba) & CP 65-357 & CP357 & EU196424 \\
\hline 1.E & Tucumán (Los Córdoba) & CP 65-357 & CP357 & EU196425 \\
\hline 1.F & Tucumán (Los Córdoba) & CP 65-357 & CP357 & EU196426 \\
\hline $1 . \mathrm{G}$ & Tucumán (Santa Ana) & CP 65-357 & CP357 & EU196427 \\
\hline 1.H & Tucumán (Mercedes) & TUC 93-89 & T89 & EU196428 \\
\hline 1.I & Tucumán (Los Córdoba) & TUC 95-17 & $\mathrm{T} 17$ & EU196429 \\
\hline 1.J & Tucumán (Los Córdoba) & TUC 95-17 & $\mathrm{T} 17$ & EU196430 \\
\hline $1 . \mathrm{K}$ & Tucumán (Santa Ana) & TUC 95-59 & T59 & EU196431 \\
\hline 1.L & Tucumán (Santa Ana) & TUC 95-59 & T59 & EU196432 \\
\hline 1.M & Tucumán (Santa Ana) & TUC 95-59 & T59 & EU196433 \\
\hline $1 . \mathrm{N}$ & Salta (Colonia Santa Rosa) & CO 419 & C0419 & EU196434 \\
\hline $1 . \mathrm{O}$ & Salta (Colonia Santa Rosa) & $\mathrm{CO} 419$ & C0419 & EU196435 \\
\hline 2.A & Tucumán (Santa Ana) & TUC 94-58 & T58 & EU196436 \\
\hline 2.B & Tucumán (Santa Ana) & TUC 94-58 & T58 & EU196437 \\
\hline 2.C & Tucumán (Santa Ana) & TUC 94-58 & T58 & EU196439 \\
\hline 2.D & Tucumán (Las Talitas) & RA 87-3 & RA3 & EU196440 \\
\hline 2.E & Salta (Colonia Santa Rosa) & NA 89-104 & NA104 & EU196441 \\
\hline 3.A & Tucumán (Mercedes) & TUC 95-17 & $\mathrm{T} 17$ & EU196442 \\
\hline 3.B & Tucumán (Mercedes) & TUC 95-17 & $\mathrm{T} 17$ & EU196443 \\
\hline 3.C & Tucumán (Mercedes) & TUC 95-17 & $\mathrm{T} 17$ & EU196444 \\
\hline 3.D & Tucumán (Mercedes) & TUC 95-17 & $\mathrm{T} 17$ & EU196445 \\
\hline 3.E & Tucumán (Los Córdoba) & TUC 95-17 & $\mathrm{T} 17$ & EU196446 \\
\hline 4.A & Jujuy (Ledesma) & NA $84-3419$ & NA3419 & EU196447 \\
\hline 4.B & Jujuy (Ledesma) & NA 84-3419 & NA3419 & EU196448 \\
\hline 5.A & Tucumán (Yaquilo) & CP 65-357 & CP357 & EU196449 \\
\hline 6.A & Tucumán (Los Córdoba) & TUC 93-104 & T104 & EU196450 \\
\hline $6 . \mathrm{B}$ & Tucumán (Los Córdoba) & TUC 93-104 & $\mathrm{T} 104$ & EU196451 \\
\hline 7.A & Tucumán (Las Talitas) & RA 87-3 & RA3 & EU196452 \\
\hline 7.B & Tucumán (Las Talitas) & RA $87-3$ & RA3 & EU196453 \\
\hline 8.A & Salta (Colonia Santa Rosa) & NA 90-244 & NA244 & EU196454 \\
\hline 8.B & Salta (Colonia Santa Rosa) & NA 90-244 & NA244 & EU196455 \\
\hline 9.A & Salta (Colonia Santa Rosa) & NA 87-661 & NA661 & EU196438 \\
\hline \multicolumn{5}{|l|}{ SrMV } \\
\hline H.1 & Tucumán (Mercedes) & TUC 94-12 & $\mathrm{T} 12$ & EU189035 \\
\hline H.2 & Tucumán (Mercedes) & CP 65-357 & CP357 & EU189036 \\
\hline H.3 & Tucumán (Mercedes) & CP 65-357 & CP357 & EU189037 \\
\hline M.1 & Tucumán (Los Córdoba) & TUC 93-58 & T58 & EU189039 \\
\hline M.2 & Tucumán (Santa Ana) & TUC 96-27 & $\mathrm{T} 27$ & EU189040 \\
\hline I. 1 & Tucumán (Yaquilo) & TUC 96-24 & $\mathrm{T} 24$ & EU189041 \\
\hline I. 2 & Tucumán (Yaquilo) & TUC 96-24 & $\mathrm{T} 24$ & EU189042 \\
\hline I.3 & Tucumán (Yaquilo) & TUC 96-24 & $\mathrm{T} 24$ & EU189038 \\
\hline I.4 & Tucumán (Palá Palá) & TUC 93-104 & $\mathrm{T} 104$ & EU189043 \\
\hline I.5 & Tucumán (Palá Palá) & TUC 93-104 & $\mathrm{T} 104$ & EU189044 \\
\hline I.6 & Tucumán (Palá Palá) & TUC 93-104 & $\mathrm{T} 104$ & EU189045 \\
\hline I.7 & Tucumán (Santa Ana) & TUC 96-27 & $\mathrm{T} 27$ & EU189046 \\
\hline
\end{tabular}

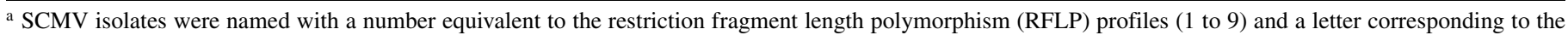
different isolates belonging to each profile. SrMV isolates were designated with a letter corresponding to the three RFLP profiles (M, H, and I) and a number corresponding to the different isolates belonging to each profile.

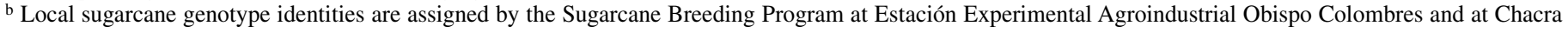
Experimental Colonia Santa Rosa.

c Genotype abbreviation used for isolate designation in phylogenetic analysis. 
correlation between host genotype and the sequence of the SCMV $\mathrm{CP}$ gene has been reported (37), indicating that infected hosts may have exerted a selection pressure for virus evolution. We have found a weak correlation among viruses isolated from the same sugarcane genotypes, especially for SCMV (Fig. 5).

Detection of SCMV subgroup members and SCSMV. When the primer set Oligo1n and Oligo2n (26) was used to detect the members of the SCMV subgroup, an expected fragment of $327 \mathrm{bp}$ was amplified in all the samples (data not shown). The RFLP profile analysis allowed us to detect only SCMV and SrMV from the four original members of the subgroup (SCMV, SrMV, MDMV, and JGMV). We found two RFLP profiles for SCMV, one belonging to strain $\mathrm{E}(8.3 \%$ of the samples; fragment sizes with $A l u \mathrm{I}=6,35,50,75,79$, and 82 bp and with $D d e \mathrm{I}=34,56$, and $237 \mathrm{bp}$ ) and the other belonging either to strains B or D (91.7\% of the samples; fragment sizes with $A l u \mathrm{I}=6,35,50,82$,
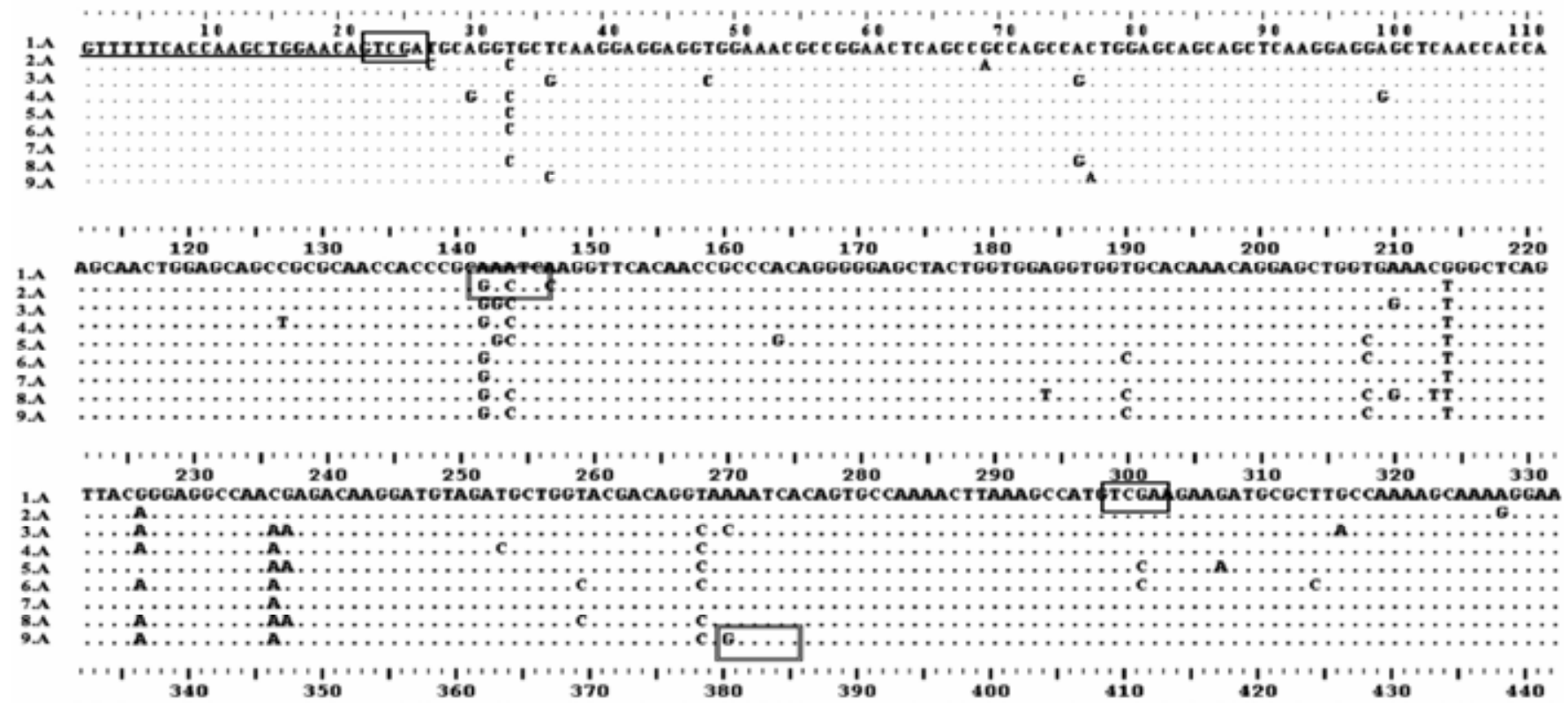

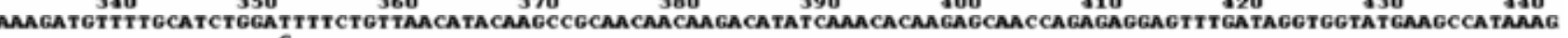
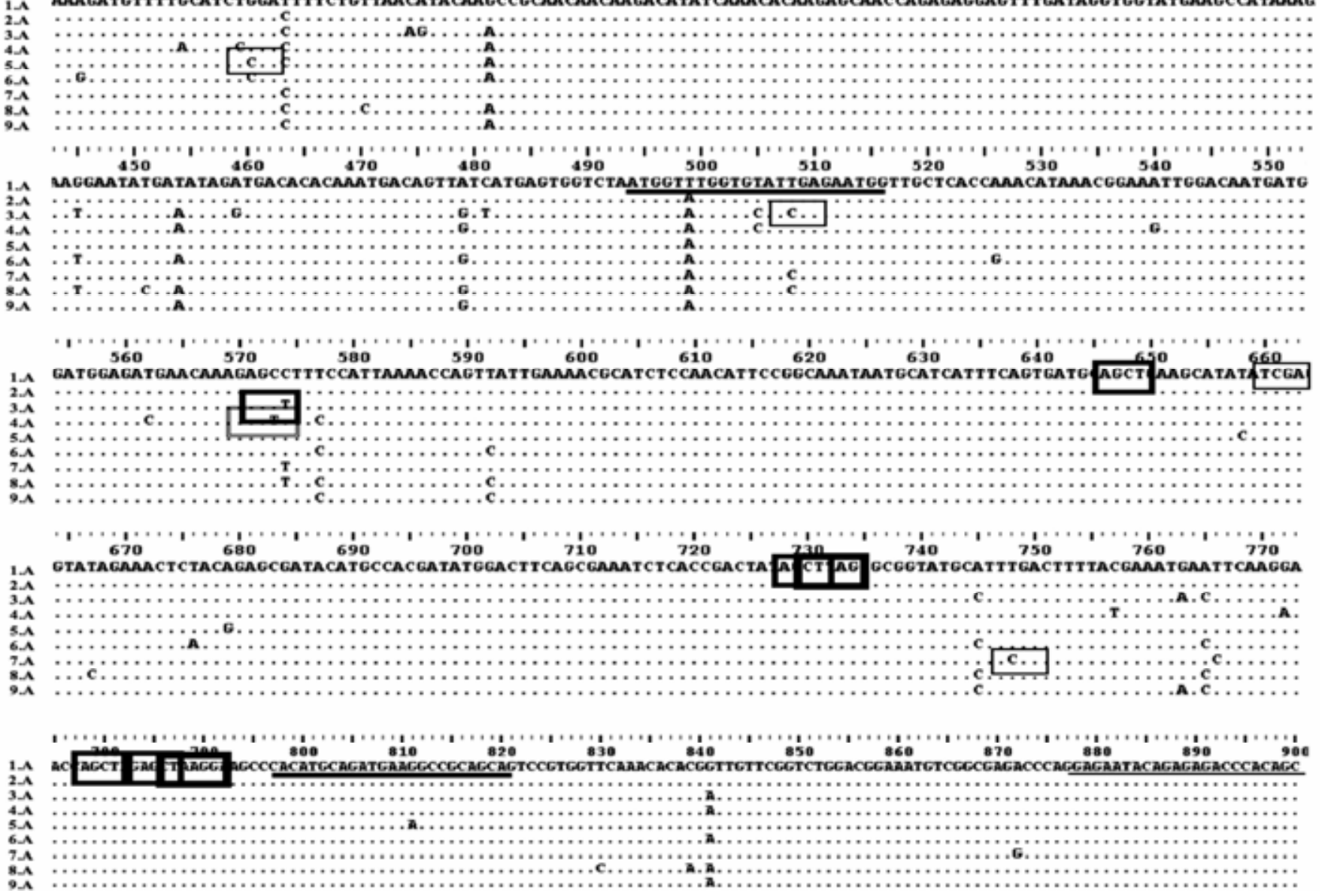

Fig. 3. Multiple alignment of nucleotide sequences of coat protein genes from one Sugarcane mosaic virus (SCMV) isolate of each of the nine restriction fragment length polymorphism profiles. The rectangles indicate cleavage sites of (thin line), TaqI; (double line), HinfI; (medium bold line), AluI; and (bold line), DdeI. Primer sequences are underlined: (thin line) $=$ SCMVF4 and SCMVR3 and (medium bold line) $=$ Oligo $1 \mathrm{n}$ and Oligo2n 
and $154 \mathrm{bp}$ and with $D d e \mathrm{I}=34,56$, and $237 \mathrm{bp}$ ). The only RFLP profile found for SrMV may belong to strain M or I (fragment sizes with $A l u \mathrm{I}=35,138$, and $154 \mathrm{bp}$ and with $D d e \mathrm{I}=327 \mathrm{bp}$ ). Nevertheless, this strain classification for each virus, based on the theoretical profiles proposed by Marie-Jeanne et al. (26), did not coincide with those obtained when using the protocol of Yang and Mirkov (38). This may be because the protocol described by Marie-Jeanne et al. (26) was not designed to differentiate virus strains. In other words, it shows less genetic diversity than the Yang and Mirkov (38) technique.

None of the leaf samples produced an RT-PCR product when SCSMV-specific primers ST2 and ST5 were used (8) (data not shown),

\section{DISCUSSION}

Sugarcane mosaic has been reported in more than 70 countries and, because the published strains have been described from only a few of these countries (19), the number of existing SCMV and SrMV strains is expected to be much greater. Currently, the major reported genetic diversity of SCMV in sugarcane and maize has been found from sampling conducted in the United States, Germany, China, Australia, and four African countries (3). In Argentina, there are a few reports of viruses related to sugarcane mosaic. SCMV strain B was the pathogen first identified by biological assays (5). Forty years later, two additional SCMV strains (A and F) were found by a similar approach. SrMV strain I was also detected in sugarcane with mosaic symptoms (29). In 2005, the predominance of SCMV strain E in Tucumán was determined by an RT-PCR-based RFLP technique (13). Recently, using the same methodology, we were unable to assign all the obtained RFLP profiles to known strains (27). In the present work, we found new SCMV and SrMV genotypes predominantly associated with mosaic disease in Argentina. Currently, other than SCMV strain E, the major strain identified by RT-PCR-based RFLPs in our region belongs to an unknown profile that did not match any known strains (Table 2). These changes in strain identity could be explained by changes in the sugarcane cultivars used in the region, as illustrated by the history of SCMV strains in Louisiana $(20,24)$, where new strains appeared when new cultivars were grown. We found no correlation between SCMV isolates in Tucumán, Salta, and Jujuy and their geographical distribution. This may be due to the fact that different sugarcane genotypes were sampled in the three regions and, as Espejel et al. (12) and Gemechu et al. (15) have reported, SCMV distribution seems to be more related to host than to geographical origin. In fact, data obtained by Goodman (17) indicate clearly that no association exists between SCMV strain prevalence and specific cultivars or regions.

In Tucumán, the sugarcane breeding program was established 40 years ago and resistance to mosaic remains a major selection criterion. In order to obtain genetic variability in agronomical traits, this breeding program is constantly importing foreign germplasm, mainly from Louisiana, that, after quarantine, is incorporating into the crossing schedule. However, all SCMV sequences reported in this study had a higher nucleotide identity with isolates from Australia than those from the United States (Table 4). A similar situation has been reported by Gonçalves et al. in Brazil (16). In contrast, SrMV was detected only in samples from Tucumán, and their sequences had a higher nucleotide identity with U.S. isolates (Fig. 5; Table 5). These results indicate that sugarcane quarantine is effective at preventing the spread of
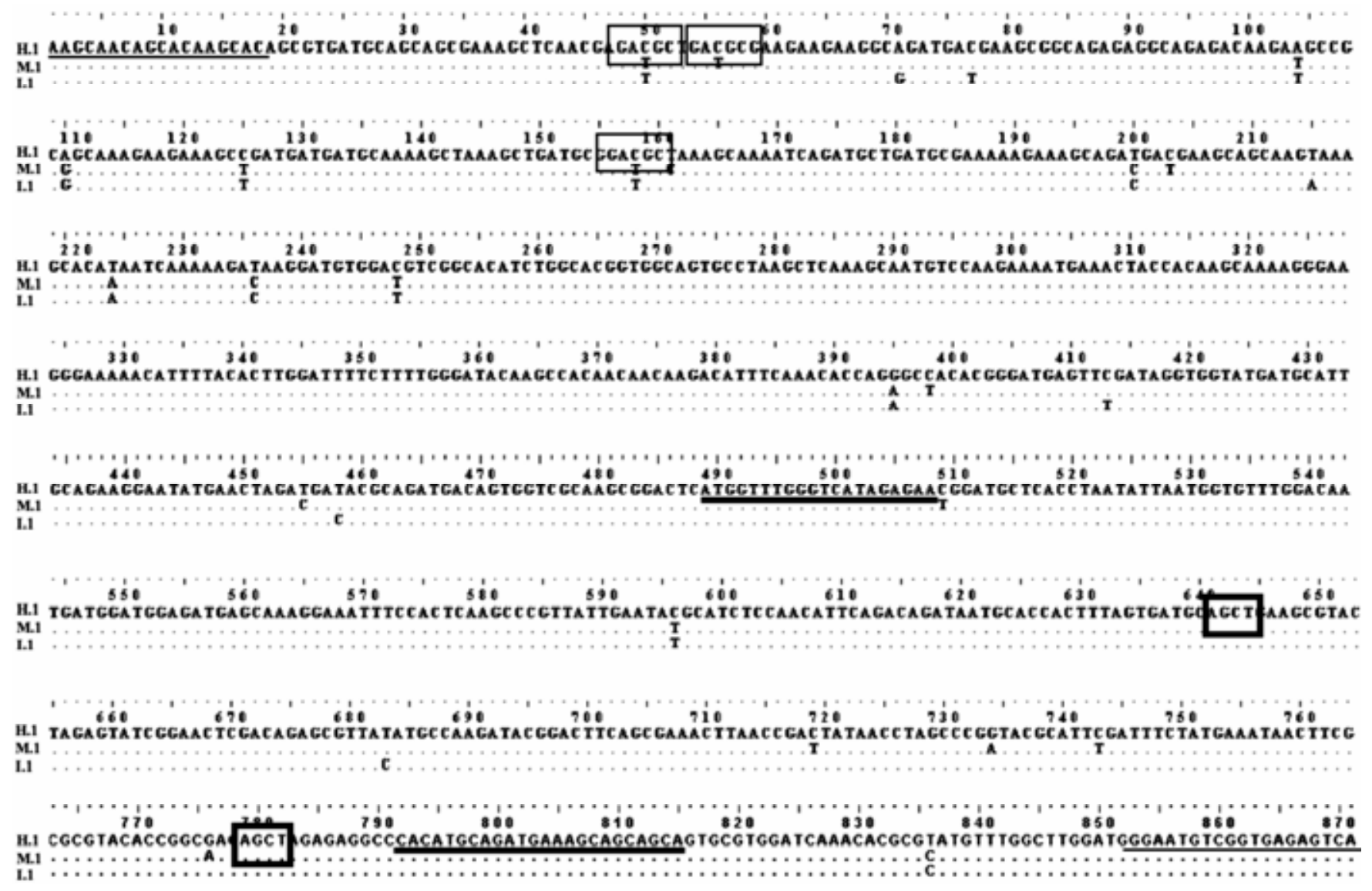

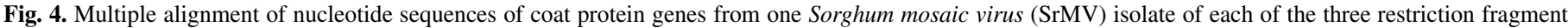

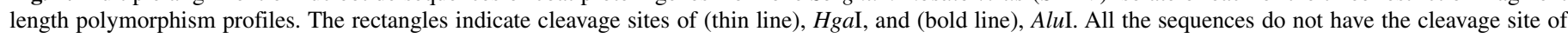
DdeI. Primer sequences are underlined: (thin line) $=$ SrMVF4 and SrMVR3 and (bold line) = Oligo1n and Oligo $2 \mathrm{n}$. 
SCMV, because detection has been optimized and is routinely carried out (28). However, the SrMV diagnostic technique needs to be urgently implemented in order to avoid SrMV introduction, as seems to have happened in the past. The results also reinforce the importance of proper implementation of quarantine and diagnostic protocols for germplasm exchange to prevent the introduction of new pathogens or new strains into sugarcane-growing locations (11). Moreover, we found a greater genetic variability in our region compared with that determined by Handley et al. (22) for Australia, the United States, and South Africa, where similar values of variability among SCMV isolates were found. In addition, this genetic variability in the nucleotide sequences of SCMV $(0.12$ to $4.11 \%)$ and SrMV (0.12 to $2.64 \%)$ in sugarcane should be taken into consideration in the local breeding program for resistance to mosaic disease.

Koike and Gillaspie (24) suggested that mixtures of strains might become unstable, resulting in one strain becoming dominant. Joint infection by related viruses is unusual but does seem to occur in some vegetatively propagated crops (9). In this respect, although there have been many studies in which specific primers for SCMV and SrMV were used jointly, there has been only one report of the coexistence of both in sugarcane (10). In our work, we detected a high frequency of co-infection $(68.4 \%)$ by SCMV and SrMV in Tucumán, whereas no co-infection was found in the other two provinces (Salta and Jujuy). The high co-infection in Tucumán may be the consequence of the use of different sugarcane genotypes, the effect of agroecological conditions, and/or the incidence of vector populations compared with other sugarcanegrowing areas in Argentina and the world.

In order to assess the range of viral genetic diversity, we did not restrict the sampling to commercially grown cultivars; instead, we

TABLE 5. Percentage of nucleotide identity among coat protein genes of the 12 Sorghum mosaic virus (SrMV) isolates and some sequences from the GenBank corresponding to strains M (U57360) H (U57358), and I (U57359)

\begin{tabular}{lccc}
\hline & \multicolumn{3}{c}{ SrMV strains $^{\mathrm{b}}$} \\
\cline { 2 - 4 } Isolate $^{\mathrm{a}}$ & $\mathrm{H}$ & $\mathrm{M}$ & $\mathrm{I}$ \\
\hline H.1 & $\mathbf{9 7 . 6 0}$ & $\mathbf{9 7 . 1 2}$ & 97.96 \\
H.2 & $\mathbf{9 7 . 6 0}$ & 97.36 & 98.20 \\
H.3 & 97.72 & 97.48 & 98.32 \\
M.1 & 98.08 & 97.60 & $\mathbf{9 7 . 7 2}$ \\
M.2 & 98.08 & 97.60 & $\mathbf{9 7 . 7 2}$ \\
I.1 & 98.44 & 98.44 & 98.80 \\
I.2 & 98.56 & $\mathbf{9 8 . 5 6}$ & $\mathbf{9 8 . 9 2}$ \\
I.3 & 98.56 & 98.08 & 98.20 \\
I.4 & 98.32 & 98.32 & 98.68 \\
I.5 & $\mathbf{9 8 . 6 8}$ & 98.20 & 98.32 \\
I.6 & 98.56 & 98.08 & 98.20 \\
I.7 & 98.32 & 97.60 & 97.96 \\
\hline
\end{tabular}

${ }^{a}$ SrMV isolates were designated with a letter corresponding to the three restriction fragment length polymorphism profiles $(\mathrm{M}, \mathrm{H}$, and I) and a number corresponding to the different isolates belonging to each profile.

${ }^{b}$ Bold numbers represent the extreme values of nucleotide identity between the isolates and each sequence from the GenBank.

TABLE 4. Percentage of nucleotide identity among coat protein genes of the 35 Sugarcane mosaic virus (SCMV) isolates and some sequences from the GenBank corresponding to strains from the United States and isolates from Australia (AF006735 and AJ278405)

\begin{tabular}{|c|c|c|c|c|c|c|}
\hline \multirow[b]{2}{*}{ Isolate $^{b}$} & \multicolumn{6}{|c|}{ SCMV strains ${ }^{\mathrm{a}}$} \\
\hline & A & B & $\mathrm{D}$ & $\mathrm{E}$ & AF00 6735 & AJ278 405 \\
\hline 1.A & 93.90 & 94.01 & 94.72 & 95.89 & 97.42 & 99.21 \\
\hline 1.B & 93.66 & 93.78 & 94.48 & 95.66 & 97.18 & 99.20 \\
\hline 1.D & 93.43 & 94.13 & 94.84 & 95.77 & 96.83 & 99.18 \\
\hline 1.E & 93.66 & 94.37 & 95.07 & 95.77 & 97.07 & 99.17 \\
\hline $1 . \mathrm{F}$ & 93.54 & 94.25 & 94.95 & 95.66 & 96.95 & 99.16 \\
\hline 1.J & 94.01 & 94.48 & 94.95 & 96.13 & 97.42 & 99.12 \\
\hline $1 . \mathrm{K}$ & 93.90 & 94.25 & 95.19 & 97.07 & 97.42 & 99.11 \\
\hline 1.L & 93.78 & 94.13 & 95.07 & 96.95 & 97.30 & 99.10 \\
\hline 1.M & 93.66 & 94.01 & 94.95 & 96.83 & 97.18 & 99.90 \\
\hline $1 . \mathrm{N}$ & 93.90 & 94.25 & 94.72 & 96.83 & 97.89 & 99.80 \\
\hline 1.0 & 93.78 & 94.25 & 94.72 & 96.71 & 97.77 & 99.70 \\
\hline 3.A & 92.84 & 93.90 & 94.37 & 96.24 & 96.60 & 99.10 \\
\hline 3.B & 93.08 & 94.13 & 94.60 & 96.48 & 96.83 & 99.00 \\
\hline 3.C & 93.90 & 94.13 & 95.07 & 96.24 & 96.83 & 99.10 \\
\hline 3.D & 93.90 & 94.13 & 95.07 & 96.24 & 96.83 & 99.20 \\
\hline 3.E & 92.96 & 94.01 & 94.48 & 96.36 & 96.71 & 99.30 \\
\hline 4.A & 94.48 & 95.42 & 95.89 & 96.36 & 97.89 & 99.40 \\
\hline 4.B & 94.48 & 95.42 & 95.89 & 96.36 & 97.89 & 99.50 \\
\hline 5.A & 93.54 & 94.01 & 94.60 & 95.89 & 96.95 & 99.60 \\
\hline 6.A & 93.90 & 94.13 & 94.72 & 96.48 & 97.54 & 99.70 \\
\hline $6 . \mathrm{B}$ & 94.01 & 94.25 & 94.84 & 96.60 & 97.65 & 99.80 \\
\hline 7.A & 93.78 & 94.25 & 94.72 & 96.36 & 97.18 & 99.90 \\
\hline 7.B & 94.01 & 94.48 & 94.95 & 96.36 & 97.42 & 99.10 \\
\hline 8.A & 93.31 & 93.66 & 94.13 & 96.60 & 96.83 & 99.11 \\
\hline 8.B & 93.31 & 93.66 & 94.13 & 96.60 & 96.83 & 99.12 \\
\hline
\end{tabular}

a Strains from the United States: A = U57354, B = U57355, D = U57356, and E = U57357. Bold numbers represent the extreme values of nucleotide identity between the isolates and each sequence from the GenBank.

${ }^{\mathrm{b}}$ SCMV isolates were named with a number equivalent to the restriction fragment length polymorphism profiles (1 to 9 ) and a letter corresponding to the different isolates belonging to each profile. 
collected samples from sugarcane-breeding field trials that included advanced promising cultivars of our breeding program. In Tucumán, the commercial cv. CP 65-357, released in 1989 and currently planted in $18 \%$ of the sugarcane production area (2), was infected by several virus genotypes (Table 3 ). This confirms the high susceptibility to mosaic of this important cultivar, which was the most widely planted cultivar between 1994 and 2002, when it occupied $34 \%$ of the production area in Tucumán. Also, we found SrMV strain $\mathrm{H}$ in this cultivar by RT-PCR-based RFLPs, whereas Grisham et al. (20) reported that, in 2003 in

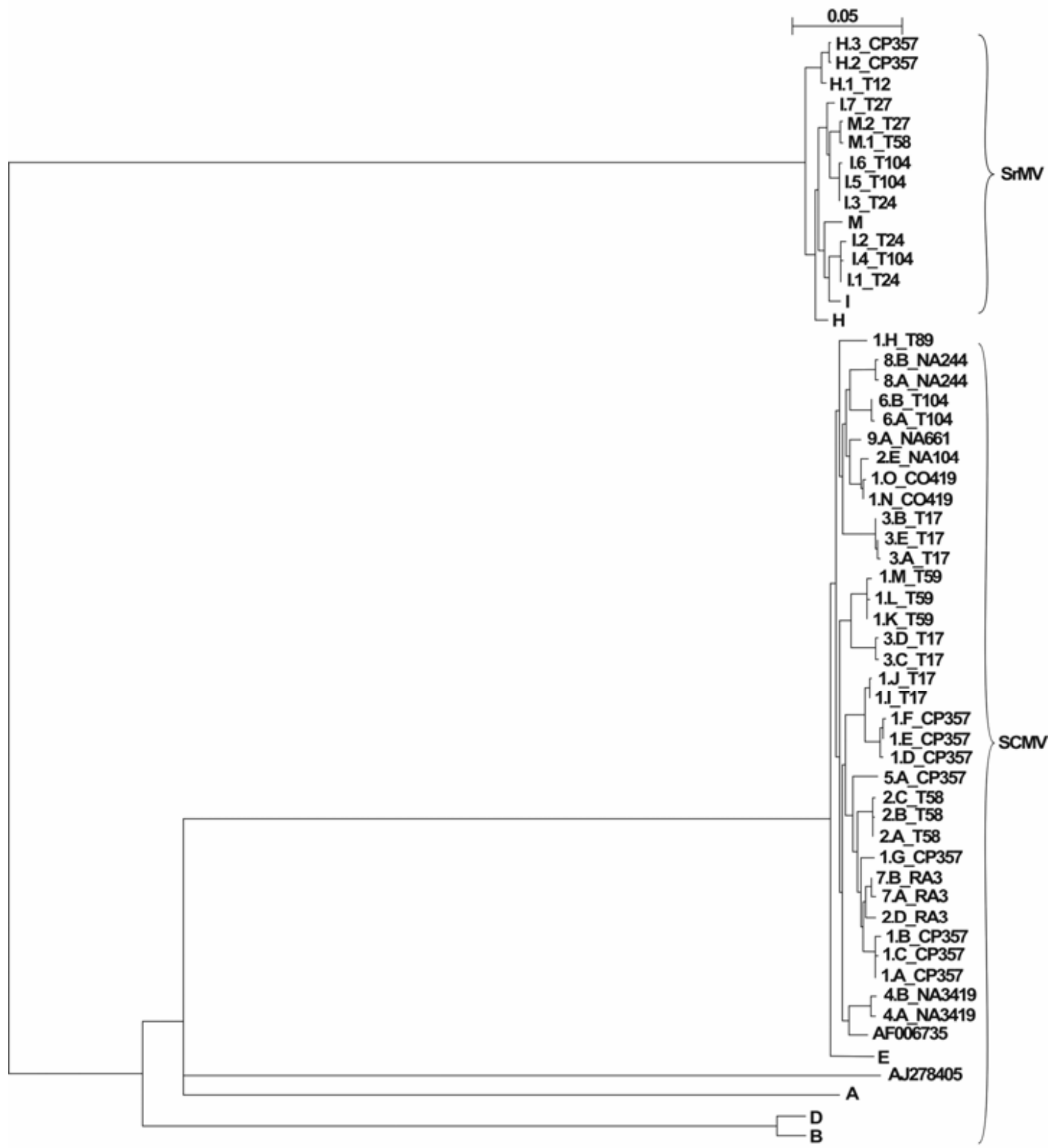

Fig. 5. Phylogenetic tree obtained with Clustal X from Sugarcane mosaic virus (SCMV) and Sorghum mosaic virus (SrMV) multiple alignment of the nucleotide sequence of the coat protein gene-amplified fragment. Abbreviations and accession number in the GenBank of known strain sequences: M (U57360), H (U57358), I (U57359), A (U57354), B (U57355), D (U57356), and E (U57357). SCMV isolates were named with a number equivalent to the restriction fragment length polymorphism (RFLP) profiles (1 to 9) and a letter corresponding to the different isolates belonging to each profile. SrMV isolates were designated with a letter corresponding to the three RFLP profiles (M, H, and I) and a number corresponding to the different isolates belonging to each profile. Local sugarcane genotype identities are assigned by the Sugarcane Breeding Program at Estación Experimental Agroindustrial Obispo Colombres and at Chacra Experimental Colonia Santa Rosa. Genotype abbreviations were used for the purpose of this phylogenetic analysis. 
Louisiana, CP 65-357 was infected with SrMV strain I. This was in contrast to what had been found in earlier surveys, with SrMV strain $\mathrm{H}$ being the most commonly recorded one (20).

SCSMV, the major cause of mosaic symptoms in commercial sugarcane cultivars in several Asian countries (8), was not detected in the sugarcane leaves with mosaic symptoms in our region. However, this virus was recently found in a germplasm collection in Colombia (7), indicating the importance of establishing a standard diagnostic protocol for SCSMV detection in quarantine stages.

The characterization of symptoms produced on differential hosts is time consuming, and reliable studies require the use of a set of standard differential hosts and previously described viral strains. These conditions are rarely met (3). The RT-PCR-based RFLP method of CP genes proposed by Yang and Mirkov (38) should facilitate a rapid identification and discrimination of strains from unknown field isolates. The $\mathrm{CP}$ is the best characterized of all the gene products and consists of the highly variable, surface-exposed amino-(N)-terminus, a highly conserved core region, and a surface-exposed carboxyl-C-terminus (31). The $\mathrm{N}$-terminus is the most significant region in the virus in that it is unique to each viral type and, thus, is the region where most strain variation occurs (18). In the present work, when RFLP analysis was performed on the RT-PCR products derived from the SCMV-specific primer set, $59 \%$ of the samples produced banding patterns that did not match with those for known strains (Table 2). Consequently, a single mutation is sufficient for an isolate to lose a restriction site and hamper typing by this method (26). All the SCMV sequences belonging to the nine RFLP profiles obtained (Table 2) have a higher nucleotide identity with SCMV strain E than with any of the other strains reported by Yang and Mirkov (38). On the other hand, SrMV strains $\mathrm{H}$ and $\mathrm{M}$ and some of strain I predicted by RFLP analysis do not exhibit a higher nucleotide identity with the corresponding strain. Also, the protocol proposed by MarieJeanne et al. (26), used to detect SCMV subgroup members, was inefficient in differentiating strains based on the RFLP analysis. Our results question the RFLP method to discriminate strains. Not only does this technique fail to detect the entire range of genetic diversity of the viruses but it also might mask differences. Goodman (17) found that the results obtained using the simple RFLP technique for SCMV strain identification were not in complete agreement with those obtained using sequence comparisons of the CP gene fragments. Today, DNA sequence data are only one of the sources of information used in virus classification. However, this source is becoming increasingly important, with the $\mathrm{CP}$ region being highly discriminatory for diagnostic and taxonomic studies if only a subportion of the genome is to be sequenced (1). Nucleotide sequence identities (and amino acid similarities) have been widely used for Potyvirus taxonomic purposes $(30,32)$, taking into consideration that all CP gene nucleotide identity percentages vary between 40 and $70 \%$ for different potyviruses and are above $90 \%$ for different strains of the same virus (14).

The results presented here using both traditional methods and DNA sequencing technology constitute the first detailed report on the characterization of sugarcane potyviruses from Argentina, and also provide the first SCMV and SrMV sequences from our country.

\section{ACKNOWLEDGMENTS}

This project was partially supported by Consejo Nacional de Investigaciones Científicas y Técnicas (CONICET) and Universidad Nacional de Tucumán (UNT). M. L. Garcia, L. D. Ploper, and A. P. Castagnaro are CONICET members. M. F. Perera is a CONICET fellow. We thank P. Rott (CIRAD, France) for providing us with the positive control for SCSMV detection and ST2 and ST5 primer sequences; A. Rago and G. Serino (Chacra Experimental Colonia, Santa Rosa, Argentina) for the infected samples from Salta and Jujuy; F. García Arenal (ETSIA,
Universidad Politécnica de Madrid, Spain) for his technical support and counseling; and M. Butterfield (SASRI, South Africa), A. Manes (EEAOC, Argentina), L. W. Timmer (University of Florida, CREC), A. M. Vázquez (Universidad Complutense de Madrid, Spain), and S. L. Giammaría (EEAOC, Argentina) for reviewing the English version of the manuscript.

\section{LITERATURE CITED}

1. Adams, M. J., Antoniw, J. F., and Fauquet, C. M. 2005. Molecular criteria for genus and species discrimination within the family Potyviridae. Arch. Virol. 150:459-479.

2. Ahmed, M. A., Cuenya, M. I., García, M. B., and Díaz Romero, C. 2007. Dinámica y características del recambio de variedades de caña de azúcar en Tucumán desde las primeras décadas del siglo XX hasta la actualidad. Av. Agroind. 28:17-22.

3. Alegria, O. M., Royer, M., Bousalem, M., Chatenet, M., Peterschmitt, M., Girard, J.-C., and Rott, P. 2003. Genetic diversity in the coat protein coding region of eighty-six Sugarcane Mosaic Virus isolates from eight countries, particularly from Cameroon and Congo. Arch. Virol. 148:357372 .

4. Aljanabi, S. M., Forget, L., and Dookun, A. 1999. An improved and rapid protocol for the isolation of polysaccharide and polyphenol-free sugarcane DNA. Plant Mol. Biol. Rep. 17:1-8.

5. Bennett, C. W. 1941. Informe sobre experimentos con el mosaico de la caña de azúcar en Tucumán, Argentina. Rev. Ind. Agric. Tucumán 31:427437.

6. Brunt, A. A. 1992. The general properties of Potyviruses. Arch. Virol. Suppl. 5:3-16.

7. Cardona G. L. M., Angel S. J. C., Angel S. F., and Victoria K. J. I. 2006. Standardization of reverse transcription polymerase chain reaction (RTPCR) for diagnosis of the Streak mosaic virus of sugarcane in Colombia. In: VIIIth ISSCT Pathology Workshop Petit-Bourg, Guadeloupe.

8. Chatenet, M., Mazarin, C., Girard, J. C., Fernandez, E., Gargani, D., Rao, G. P., Royer, M., Lockhart, B., and Rott, P. 2005. Detection of Sugarcane Streak Mosaic Virus in sugarcane from several Asian countries. Proc. Int. Soc. Sugar Cane Technol. 25:656-662.

9. Chen, J., Chen, J., and Adams, M. J. 2001. Molecular characterization of a complex mixture of viruses in garlic with mosaic symptoms in China. Arch. Virol. 146:1841-1853.

10. Chen, J., Chen, J., and Adams, M. J. 2002. Characterization of potyviruses from sugarcane and maize in China. Arch. Virol. 147:1237-1246.

11. Croft, B. J., Piggin, C. M., Wallis, E. S., and Hogarth, D. M. 1996. Sugarcane germplasm conservation and exchange. Proc. Aust. Cent. Int. Agric. Res. Canberra 67.

12. Espejel, F., Jeffers, D., Noa-Carrazana, J. C., Ruiz-Castro, S., and SilvaRosales, L. 2006. Coat protein gene sequence of a Mexican isolate of Sugarcane Mosaic Virus and its infectivity in maize and sugarcane plants. Arch. Virol. 151:409-412.

13. Fontana, P. D., Ramallo, J. C., Vellicce, G. R., Ontivero, M., Ploper, D., Diaz Ricci, J. C., and Castagnaro, A. P. 2005. Caracterización molecular de razas del virus del Mosaico de la Caña de Azúcar en Tucumán, Argentina. In: XIII Congr. Latinoamericano Fitopatol. Villa Carlos Paz, Córdoba, Argentina.

14. Frenkel, M. J., Ward, C. W., and Shukla. D. D. 1989. The use of 3' noncoding nucleotide sequences in the taxonomy of Potyviruses: application to Watermelon Mosaic Virus 2 and Soybean Mosaic Virus-N. J. Gen. Virol. 70:2775-2783.

15. Gemechu, A. L., Chiemsombat, P., Attathom, S., Reanwarakorn, K., and Lersrutaiyotin, R. 2006. Cloning and sequence analysis of coat protein gene for characterization of Sugarcane mosaic virus isolated from sugarcane and maize in Thailand. Arch. Virol. 151:167-172.

16. Gonçalvez, M. C., Santos, A. S., Maia, I. G., Chagas, C. M., and Harakava, R. 2007. Caracterização de um isolado do Sugarcane Mosaic Virus que quebra a resistência de variedades comerciais de cana-deaçúcar. Fitopatol. Bras. 32:32-39.

17. Goodman, B. S. 1999. A study of South African strains of Sugarcane Mosaic Potyvirus (SCMV) identified by sequence analysis of the 5' region of the coat protein gene. M.S. thesis, Department of Biotechnology, Durban University of Technology, Durban, South Africa.

18. Goodman, B. S., MacDonald, D., and Huckett, B. I. 1998. A survey of South African Sugarcane Mosaic Virus (SCMV) strains based on coat protein gene sequence analysis. Proc. S. Afr. Sugar Technol. Assoc. 72:146-148.

19. Grisham, M. P. 2000. Mosaic. Pages 249-254 in: A Guide to Sugarcane Diseases. P. Rott, R. A. Bailey, J. C. Comstock, B. J. Croft, and A. S. Saumtally, eds. CIRAD/ISSCT, Montpellier, France.

20. Grisham, M. P., and Pan, Y. B. 2007. A genetic shift in the virus strains that cause mosaic in Louisiana sugarcane. Plant Dis. 91:453-458. 
21. Hall, J. S., Adams, B., Parsons, T. J., French, R., Lane, L. C., and Jensen, S. G. 1998. Molecular cloning, sequencing and phylogenetic relationship of a new potyvirus: Sugarcane streak mosaic virus, and a reevaluation of the classification of the Potyviridae. Mol. Biol. Evol. 10:323-332.

22. Handley, J. A., Smith, G. R., Dale, J. L., and Harding, R. M. 1998. Sequence diversity in the coat protein coding region of twelve Sugarcane Mosaic Potyvirus isolates from Australia, USA and South Africa. Arch. Virol. 143:1145-1153.

23. Hema, M., Sreenivasulu, P., and Savithri, H. S. 2002. Taxonomic position of Sugarcane streak mosaic virus in the family Potyviridae. Arch. Virol. 147:1997-2007.

24. Koike, H., and Gillaspie, A. G., Jr. 1989. Mosaic. Pages 301-322 in: Diseases of Sugarcane: Major Diseases. C. Ricaud, B. T. Egan, A. G. Gillaspie, Jr., and C. G. Hughes, eds. Science Publishers, Amsterdam.

25. Lomonosoff, G. P. 1995. Pathogen-derived resistance to plant viruses. Annu. Rev. Phytopathol. 33:323-343.

26. Marie-Jeanne, V., Ioos, R., Peyre, J., Alliot, B., and Signoret, P. 2000. Differentiation of Poaceae Potyviruses by reverse transcriptionpolymerase chain reaction and restriction analysis. J. Phytopathol. 148:141-151.

27. Perera, M. F., Filippone, M. P., Ramallo, J., Cuenya, M. I., García, M. L., and Castagnaro, A. P. 2007. Genetic diversity of Sugarcane Mosaic Virus complex in Tucumán, Argentina. Proc. Int. Soc. Sugar Cane Technol. 26:988-994.

28. Ramallo, J., Ramallo, N. E. V., and Ploper, L. D. 2000. Diagnóstico de enfermedades de la caña de azúcar. Metodologías aplicadas por la EEAOC. Av. Agroind. 21:8-12.

29. Ramallo, N. E. V. 1981. Razas del mosaico de la caña de azúcar. Rev. Ind. Agric. Tucumán 58:57-68.
30. Rybicki, E. P., and Shukla, D. D. 1992. Coat protein phylogeny and systematic of potyviruses. Arch. Virol. Suppl. 5:139-170.

31. Shukla, D. D., Strike, P. M., Tracy, S. L., Gough, K. H., and Ward, C. W. 1988. The N- and C-termini of the coat proteins of potyviruses are surface located and the $\mathrm{N}$-terminus contains the major virus-specific epitopes. J. Gen. Virol. 69:1497-1508.

32. Shukla, D. D., and Ward, C. W. 1988. Amino acid sequence homology of coat proteins as a basis for identification and classification of the potyvirus group. J. Gen. Virol. 69:2703-2710.

33. Shukla, D. D., and Ward, C. W. 1989. Identification and classification of potyviruses on the basis of coat proteins sequences data and serology. Arch. Virol. 106:171-200.

34. Smith, G. R., and Van de Velde, R. 1994. Detection of Sugarcane mosaic virus and Fiji disease virus in diseased sugarcane using the polymerase chain reaction. Plant Dis. 78:557-561.

35. Thompson, J. D., Gibson, T. J., Plewniak, F., Jeanmougin, F., and Higgins, D. G. 1997. The CLUSTAL-X windows interface: Flexible strategies for multiple sequence alignment aided by quality analysis tools. Nucleic Acids Res. 25:4876-4882.

36. Xia, X., Melchinger, A. E., Kuntze, L., and Lübberstedt, T. 1999. Quantitative trait loci mapping of resistance to Sugarcane mosaic virus in maize. Phytopathology 89:660-666.

37. Xiao, X. W., Frenkel, M. J., Teakie, D. S., Ward, C. W., and Shukla, D. D. 1993. Sequence diversity in the surface-exposed amino-terminal region of the coat proteins of seven strains of Sugarcane mosaic virus correlates with their host range. Arch. Virol. 132:399-408.

38. Yang, Z. N., and Mirkov, T. E. 1997. Sequence and relationships of sugarcane mosaic and sorghum mosaic virus strains and development of RTPCR-based RFLPs for strain discrimination. Phytopathology 87:932-939. 